\title{
Viability of Large- and Small-Sized Adults in Fluctuating Vole Populations
}

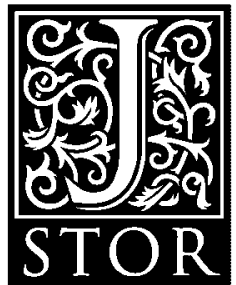

\author{
Rudy Boonstra; Charles J. Krebs \\ Ecology, Vol. 60, No. 3 (Jun., 1979), 567-573.
}

Stable URL:

http://links.jstor.org/sici?sici=0012-9658\%28197906\%2960\%3A3\%3C567\%3AVOLASA\%3E2.0.CO\%3B2-U

Your use of the JSTOR archive indicates your acceptance of JSTOR's Terms and Conditions of Use, available at http://www.jstor.org/about/terms.html. JSTOR's Terms and Conditions of Use provides, in part, that unless you have obtained prior permission, you may not download an entire issue of a journal or multiple copies of articles, and you may use content in the JSTOR archive only for your personal, non-commercial use.

Each copy of any part of a JSTOR transmission must contain the same copyright notice that appears on the screen or printed page of such transmission.

Ecology is published by The Ecological Society of America. Please contact the publisher for further permissions regarding the use of this work. Publisher contact information may be obtained at http://www.jstor.org/journals/esa.html.

Ecology

(C)1979 The Ecological Society of America

JSTOR and the JSTOR logo are trademarks of JSTOR, and are Registered in the U.S. Patent and Trademark Office. For more information on JSTOR contact jstor-info@umich.edu.

C2003 JSTOR 


\title{
VIABILITY OF LARGE- AND SMALL-SIZED ADULTS IN FLUCTUATING VOLE POPULATIONS ${ }^{1}$
}

\author{
Rudy Boonstra ${ }^{2}$ AND Charles J. KREBS \\ Institute of Animal Resource Ecology, University of British Columbia, \\ Vancouver, Canada V6T 1 W5
}

\begin{abstract}
Peak populations of many species of lemmings and voles contain adults $20-30 \%$ larger than adults found in low populations (the Chitty effect). What is the adaptive advantage of being large? We try to answer this question by analyzing the survival rates of large- and small-size adults of 4 Microtus species.

Two alternative hypotheses are proposed to explain the adaptive value of large size. Large adults may be r-selected genotypes at an adaptive advantage in increasing populations. Microtus pennsylvanicus and male $M$. townsendii fit this alternative because the survival advantage of large size is positively related to population growth rate and negatively related to density. Alternatively, large adults may be $\alpha$-selected genotypes at an adaptive advantage in high density populations when aggression is important. Microtus californicus and $M$. ochrogaster fit this hypothesis because in these species the survival advantage of large size is positively related to density and negatively related to population growth rate. Thus large body size may be adaptive for quite contrary reasons in different species of cyclic voles and lemmings.
\end{abstract}

Key words: a-selection; body size; British Columbia; Chitty effect; demography; Microtus; Rodentia; r-selection; vole cycles.

\section{INTRODUCTION}

Peak populations of lemmings and voles typically contain adults $20-30 \%$ larger than the adults found in low or declining populations. This phenomenon we call the Chitty effect because it was first described in detail by Chitty (1952) for fluctuating populations of Microtus agrestis. It has since been described in cyclic populations of Clethrionomys glareolus (Hansson 1969), C. rufocanus (Kalela 1957), C. rutilus (Koshkina and Korotkov 1975), Lemmus sibiricus and Dicrostonyx groenlandicus (Krebs 1964a, . Fuller et al. 1975), Microtus californicus (Krebs 1966, Batzli and Pitelka 1971), M. pennsylvanicus and M. ochrogaster (Krebs et al. 1969), M. arvalis (Zimmermann 1955, Stein 1957), and Synaptomys cooperi (Gaines et al. 1977). A few fluctuating populations fail to show this effect (Gaines and Rose 1976, Fuller 1977).

The origin of these large adults remains a mystery. They are not simply older animals or fatter individuals, but show a change in skeletal proportions (Krebs 1964b). We suspect that these large individuals could be 1 of Chitty's hypothetical genotypes (Chitty 1967), but there is no critical evidence so far that this is the case. In this paper we seek a partial answer to the question: What is the advantage of being large? We consider the relative viability of adult voles of large and small body size. Detailed mark-and-recapture data are available for 4 species: Microtus californicus, $\boldsymbol{M}$. ochrogaster, M. pennsylvanicus, and M. townsendii. Populations of all these species fluctuate greatly in numbers.

\footnotetext{
${ }^{1}$ Manuscript received 10 July 1978; accepted 24 October 1978.

${ }^{2}$ Present address: Division of Life Sciences, Scarborough College, University of Toronto, West Hill, Ontario M1C 1 A4 Canada.
}

\section{Methods}

Mark-and-recapture data were gathered by livetrapping with Longworth live-traps for $2 \mathrm{~d}$ every 2 nd wk, yr-round. Details of the areas trapped and the trapping techniques, which differed only slightly from 1 species to the next, are described in Krebs (1966) for M. californicus, Krebs et al. (1969) for M. ochrogaster and $M$. pennsylvanicus, and LeDuc and Krebs (1975) for M. townsendii.

We restricted our analysis to adult voles, virtually all of which would thus be in breeding condition during the reproductive period. Within the adult size class, we distinguished large and small adults on the basis of body wt. We did our analysis wk by wk so it was possible for an individual vole to move from 1 group to another if it gained or lost wt. Obviously pregnant females were excluded from the analysis. We recognize that divisions based on body wt are sloppy and that this adds some noise to our measurements. The wt divisions we used for each species were as follows:

\begin{tabular}{|c|c|c|}
\hline & $\begin{array}{l}\text { Small-size } \\
\text { adults (g) }\end{array}$ & $\begin{array}{l}\text { Large-siz } \\
\text { adults (g }\end{array}$ \\
\hline \multicolumn{3}{|c|}{ M. californicus } \\
\hline $\begin{array}{l}\text { males } \\
\text { females }\end{array}$ & $\begin{array}{l}40-55 \\
36-51\end{array}$ & $\begin{array}{l}\geqslant 56 \\
\geqslant 52\end{array}$ \\
\hline \multicolumn{3}{|c|}{ M. ochrogaster } \\
\hline $\begin{array}{l}\text { males } \\
\text { females }\end{array}$ & $\begin{array}{l}30-37 \\
28-36\end{array}$ & $\begin{array}{l}\geqslant 38 \\
\geqslant 37\end{array}$ \\
\hline \multicolumn{3}{|c|}{ M. pennsylvanicus } \\
\hline $\begin{array}{l}\text { males } \\
\text { females }\end{array}$ & $\begin{array}{l}34.42 \\
30-39\end{array}$ & $\begin{array}{l}\geqslant 43 \\
\geqslant 40\end{array}$ \\
\hline \multicolumn{3}{|l|}{ M. townsendii } \\
\hline $\begin{array}{l}\text { males } \\
\text { females }\end{array}$ & $\begin{array}{l}43-59 \\
40-54\end{array}$ & $\begin{array}{l}\geqslant 60 \\
\geqslant 55\end{array}$ \\
\hline
\end{tabular}

These wt divisions are completely arbitrary and were set to approximately equalize the sample sizes in the 
small and "large categories. We calculated minimum survival rates for these 2 classes for each wk of trapping. If there were no representatives from 1 of the classes present in a given wk, we eliminated all that wk data from consideration in order to preserve a balanced design. Minimum survival rates are defined as:

$$
\begin{aligned}
& \text { minimum survival rate number of the } \mathrm{x} \text { individuals } \\
& \text { from } t \text { to } t+2 w k=\frac{\text { known to be alive at time } t+2}{x \text { number of individuals caught }} \\
& \text { and released at time } t
\end{aligned}
$$

These rates will approach true survival rates only when trappability is good; but we have no reason to suspect that this bias differs beween small- and largesize adults.

Because of small sample size we had to pool the survival rates over breeding and nonbreeding periods each yr for M. californicus, M. ochrogaster, and $M$. pennsylvanicus. We eliminated periods for which sample size of either group was $<20$ voles. Sample size was larger for most $M$. townsendii populations, and we were able to analyze these data both by wk and by breeding periods. We got exactly the same answer for $M$. townsendii for these 2 time groupings, and hence we use the pooled data here. In all cases in the remainder of this paper the term sample size means the number of periods (summer 1967, winter 1967-68, etc.).

Within periods survival rates were averaged in a weighted survival rate. All survival rates in this paper are finite rates $/ 2$ wk. Pooled survival rates averaged over several periods and several grids are always geometric mean survival rates, and hence unweighted averages. Population density was arithmetically averaged over each period, and population growth rate was similarly averaged as the instantaneous rate of population change per 2 -wk interval. The standard convention of $*(P<.05)$ and $* *(P<.01)$ will be used for statistically significant effects.

\section{RESUlTS}

Microtus californicus

Six populations of Microtus californicus provided data for this analysis (Krebs 1966). Large-size adults were present only during the breeding season (November to June) and any large animals surviving at the start of the dry season soon disappeared. We assume that this means that relative viability of large and small adults is relevant only during the breeding season for this species.

Table 1 summarizes the results for Microtus californicus. During the breeding season there is always an advantage to being large in this species, an advantage of .06 survival rate $/ 2$ wk (or an $11 \%$ advantage) in males and .03 (or a $4 \%$ advantage) in females. Furthermore, the advantage of being large is greater in dense populations (Fig. 1), particularly for males.

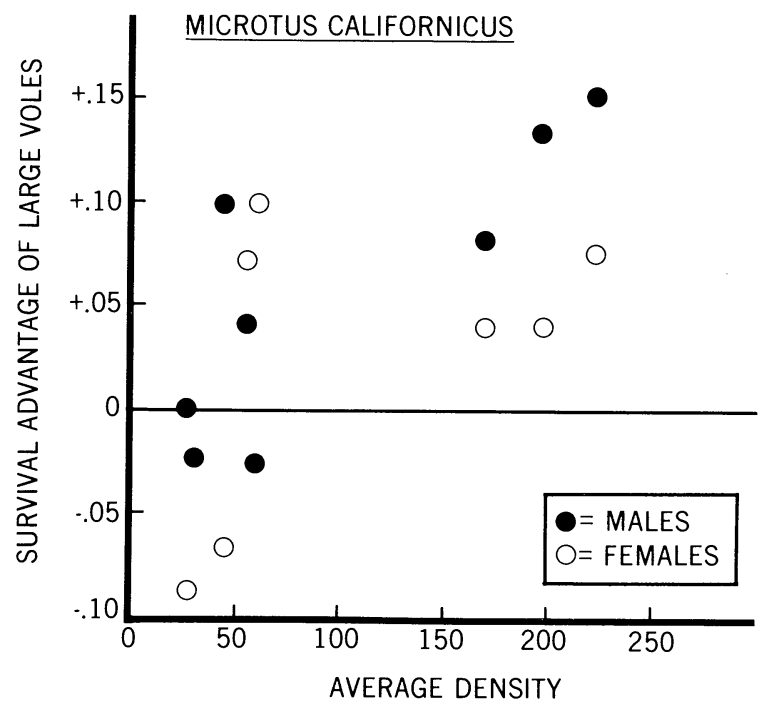

FIg. 1. Survival advantage (large adult survival rate small adult survival rate) in relation to average population density on 0.7-ha areas for Microtus californicus. Only summer breeding periods are plotted.

There is no suggestion that the advantage of being large is any different in increasing populations than it is in declining populations.

\section{Microtus ochrogaster}

Four populations of Microtus ochrogaster provided data from 19 periods (Krebs et al. 1969, Krebs 1971). These data were divided into 3 categories: summer breeding periods, winter breeding periods, and winter nonbreeding periods. Table 2 summarizes the survival differentials observed in these periods, and shows that larger M. ochrogaster have no overall advantage. But

TABle 1. Pooled survival data for large and small adults of Microtus californicus from 6 populations near Berkeley, California. Survival differential is calculated as (large adult survival rate - small adult survival rate). Survival rates are expressed as finite rates/2 wk

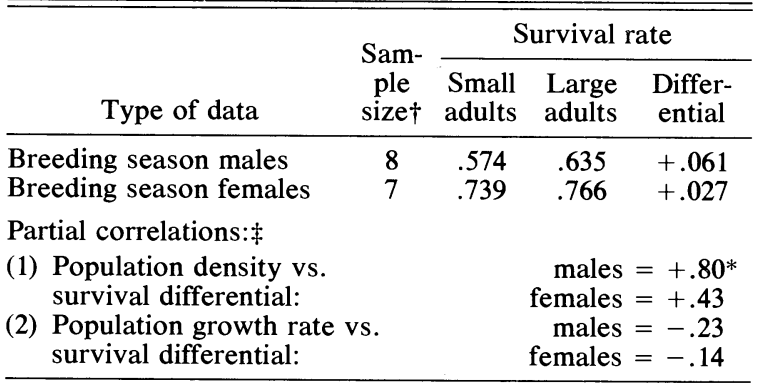

* Indicates significance at the $5 \%$ level.

$\dagger$ Sample size is number of breeding seasons summed for all areas.

$\$$ Partial correlations are determined from the correlations among average population density, average population rate of increase, and survival differential. 
TABLE 2. Survival rates for large and small adults of Microtus ochrogaster from southern Indiana. Survival differential is calculated as (large adult survival rate - small adult survival rate)

\begin{tabular}{|c|c|c|c|c|c|c|c|}
\hline \multirow[b]{2}{*}{$\begin{array}{l}\text { Type of data } \\
\text { (seasons) }\end{array}$} & \multirow[b]{2}{*}{$\begin{array}{c}\text { Sample } \\
\text { size* }\end{array}$} & \multicolumn{3}{|c|}{ Males } & \multicolumn{3}{|c|}{ Females } \\
\hline & & $\begin{array}{l}\text { Small } \\
\text { adults }\end{array}$ & $\begin{array}{l}\text { Large } \\
\text { adults }\end{array}$ & $\begin{array}{l}\text { Differ- } \\
\text { ential }\end{array}$ & $\begin{array}{l}\text { Small } \\
\text { adults }\end{array}$ & $\begin{array}{l}\text { Large } \\
\text { adults }\end{array}$ & $\begin{array}{l}\text { Differ- } \\
\text { ential }\end{array}$ \\
\hline Summer breeding & 11 & .751 & .781 & +.030 & .759 & .800 & +.041 \\
\hline Winter breeding & 3 & .831 & .903 & +.072 & .904 & .934 & +.030 \\
\hline Winter nonbreeding & 5 & .719 & .644 & -.075 & .692 & .57 .8 & -.114 \\
\hline All data combined $\dagger$ & 19 & .752 & .754 & +.002 & .762 & .753 & -.009 \\
\hline \multicolumn{8}{|c|}{$\begin{array}{l}\text { Partial correlations (summer breeding season only): } \\
\text { (1) Population density vs. survival differential: }\end{array}$} \\
\hline \multicolumn{5}{|c|}{ (2) Population growth rate vs. survival differential: } & $\begin{array}{l}\text { males } \\
\text { females }\end{array}$ & $\begin{array}{l}.05 \\
.35\end{array}$ & \\
\hline
\end{tabular}

* Number of seasons.

$\dagger$ Geometric mean over all seasons.

this neutrality of body size arises because of a balance between the strong advantage of being large in breeding populations (a 4-9\% advantage) and the strong disadvantage of being large during winters when no breeding occurs (a 10-16\% disadvantage). The advantage of being large seems to be accentuated in highdensity breeding populations, at least in males $(P=$ .07). Being large has the same effect in increasing as in declining populations. Thus, the pattern of survival of large adults in $M$. ochrogaster is very similar to that of $M$. californicus.

\section{Microtus pennsylvanicus}

Three populations of Microtus pennsylvanicus from southern Indiana, USA provided data from 26 periods
(Krebs et al. 1969, Myers and Krebs 1971). Three categories could again be recognized: summer breeding, winter breeding, and winter nonbreeding periods. The analysis of the $M$. pennsylvanicus data is complicated by differences between the populations. If we group all the data, we obtain no survival differentials at all, either in the summer or in the winter periods. But this null effect hides 2 significant effects (Table 3). On Grid $A$ in the summer period large adults survived better than small adults, while on Grids I and F at the same time large adult males survived less well than small adult males. In periods of winter breeding, there was no survival differential on Grid A or in the males on Grids I and F. In winters of no breeding activity males again behaved in an opposite manner, large males sur-

TABLE 3. Survival rates for large and small adults of Microtus pennsylvanicus from southern Indiana. Survival differential is calculated as (large adult survival rate - small adult survival rate). Grid A is separated from Grids I and F because the survival patterns differ significantly

\begin{tabular}{|c|c|c|c|c|c|c|c|}
\hline \multirow[b]{2}{*}{$\begin{array}{c}\text { Type of data } \\
\text { (seasons) }\end{array}$} & \multirow[b]{2}{*}{$\begin{array}{l}\text { Sample } \\
\text { size }\end{array}$} & \multicolumn{3}{|c|}{ Males } & \multicolumn{3}{|c|}{ Females } \\
\hline & & $\begin{array}{l}\text { Small } \\
\text { adults }\end{array}$ & $\begin{array}{l}\text { Large } \\
\text { adults }\end{array}$ & $\begin{array}{l}\text { Differ- } \\
\text { ential }\end{array}$ & $\begin{array}{l}\text { Small } \\
\text { adults }\end{array}$ & $\begin{array}{l}\text { Large } \\
\text { adults }\end{array}$ & $\begin{array}{l}\text { Differ- } \\
\text { ential }\end{array}$ \\
\hline \multicolumn{8}{|l|}{ Grid A } \\
\hline Summer breeding & 8 & .763 & .833 & +.070 & .845 & .860 & +.015 \\
\hline Winter breeding & 3 & .917 & .911 & -.006 & .927 & .922 & -.005 \\
\hline Winter nonbreeding & 2 & .817 & .737 & -.080 & .856 & .800 & -.056 \\
\hline \multicolumn{8}{|l|}{ Grids I and F } \\
\hline Summer breeding & 8 & .771 & .696 & -.075 & .779 & .813 & +.034 \\
\hline Winter breeding & 3 & .826 & .826 & .000 & .824 & .876 & +.052 \\
\hline Winter nonbreeding & 2 & .692 & .805 & +.113 & .786 & .737 & -.049 \\
\hline All data combined & 26 & .787 & .790 & +.003 & .831 & .832 & +.001 \\
\hline \multicolumn{5}{|c|}{ Partial correlations (summer breeding season only): } & \multicolumn{2}{|c|}{ Grid A } & $\begin{array}{l}\text { Grids I } \\
\text { and F }\end{array}$ \\
\hline \multicolumn{8}{|c|}{ (1) Population density vs. survival differential: } \\
\hline & & & & males $=$ & & & -.35 \\
\hline \multicolumn{8}{|c|}{ (2) Population growth rate vs. survival differential: } \\
\hline & & & & males $=$ & \multicolumn{2}{|c|}{-.57} & $+.73 *$ \\
\hline & & & & females $=$ & \multicolumn{2}{|c|}{+.42} & $+.72 *$ \\
\hline
\end{tabular}

\footnotetext{
* Indicates significance at the $5 \%$ level.
} 
viving less well than small males on Grid $\mathrm{A}$, but better on Grids I and F. Large size was a handicap for females on all grids when no breeding was occurring.

For adult females the survival advantage of being large seems to increase during summers of rapid population growth (Table 3). This effect is shown by females on all 3 grids, and also by adult males on Grids I and F. Males on Grid A seem to show just the opposite relationship, although it is not statistically significant.

The pattern of survival of large adults is rather cloudy for M. pennsylvanicus, but still seems different from that found in $M$. californicus and M. ochrogaster. For M. pennsylvanicus there is no indication that large voles do better at high densities, but rather that they do better in times of rapid population growth. However, this pattern is not found in males of all populations, for reasons we do not know.

\section{Microtus townsendii}

Three populations of Microtus townsendii from Vancouver, British Columbia, Canada, were livetrapped and provided data from 29 periods from 19711976 (LeDuc and Krebs 1975, Boonstra 1976, Krebs et al. 1976). Average survival rates of large and small adults are given in Table 4 for the summer breeding, winter breeding, and winter nonbreeding periods. There is a distinct dichotomy between the sexes of $M$. townsendii: large males have an overall survival advantage, but large females always suffer a survival handicap. Larger males survive better during periods of breeding, particularly during winter breeding periods, when large animals have a $9 \%$ advantage over small adults. But large males are at a slight disadvantage when breeding stops.

Correlation analysis again illustrates the difference between the sexes (Table 4). Males that are large survive better the lower the density (Fig. 2) and the more rapid the population increase. Female survival differ-

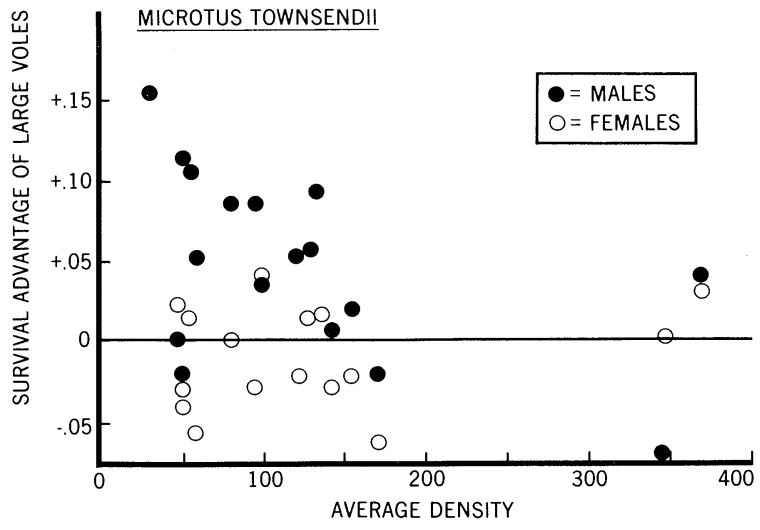

FIg. 2. Survival differential in relation to average population density on 0.7-ha areas for Microtus townsendii. Only summer breeding periods are plotted.

entials are related neither to density nor to population growth rate. Microtus townsendii is the only 1 of our 4 species in which large individuals of the 2 sexes do not have the same pattern of survival advantage.

\section{Discussion}

The change in body size of adults is one of the most striking phenomena that accompany population cycles in voles and lemmings (Krebs and Myers 1974). This effect, although clear, has proven remarkably difficult to untangle. Part of the difficulty is that body size is both age-dependent and season-dependent, and a given small-size vole or lemming may be either an animal that has not had enough time to become large, or one that will remain small. Individual voles can also lose wt during live-trapping (Bietz et al. 1977). All comparisons to date, including the ones in this paper, are subject to this type of noise and a major assumption of our analysis is that this noise has not biased our comparisons. Newson and Chitty (1962) tried to sur-

TABLE 4. Survival rates for large and small adults of Microtus townsendii from 3 control populations near Vancouver, Canada. Survival differential is calculated as (large adult survival rate - small adult survival rate)

\begin{tabular}{|c|c|c|c|c|c|c|c|}
\hline \multirow[b]{2}{*}{$\begin{array}{l}\text { Type of data } \\
\text { (seasons) }\end{array}$} & \multirow[b]{2}{*}{$\begin{array}{l}\text { Sample } \\
\text { size }\end{array}$} & \multicolumn{3}{|c|}{ Males } & \multicolumn{3}{|c|}{ Females } \\
\hline & & $\begin{array}{l}\text { Small } \\
\text { adults }\end{array}$ & $\begin{array}{l}\text { Large } \\
\text { adults }\end{array}$ & $\begin{array}{l}\text { Differ- } \\
\text { ential }\end{array}$ & $\begin{array}{l}\text { Small } \\
\text { adults }\end{array}$ & $\begin{array}{l}\text { Large } \\
\text { adults }\end{array}$ & $\begin{array}{l}\text { Differ- } \\
\text { ential }\end{array}$ \\
\hline $\begin{array}{l}\text { Summer breeding } \\
\text { Winter breeding } \\
\text { Winter nonbreeding }\end{array}$ & $\begin{array}{r}17 \\
4 \\
8\end{array}$ & $\begin{array}{l}.764 \\
.815 \\
.806\end{array}$ & $\begin{array}{l}.807 \\
.889 \\
.791\end{array}$ & $\begin{array}{l}+.043 \\
+.074 \\
-.015\end{array}$ & $\begin{array}{l}.834 \\
.905 \\
.832\end{array}$ & $\begin{array}{l}.825 \\
.881 \\
.813\end{array}$ & $\begin{array}{l}-.009 \\
-.024 \\
-.019\end{array}$ \\
\hline All data combined & 29 & .778 & .815 & +.037 & .844 & .829 & -.015 \\
\hline \multicolumn{8}{|c|}{$\begin{array}{l}\text { Partial correlations (summer breeding season only): } \\
\text { (1) Population density vs. survival differential: }\end{array}$} \\
\hline
\end{tabular}

\footnotetext{
* Indicates significance at the $5 \%$ level

** Indicates significance at the $1 \%$ level.
} 
TABLE 5. Two alternative hypotheses about the biological characteristics of the large-size voles and lemmings which characterize peak populations

\begin{tabular}{|c|c|c|}
\hline & $\begin{array}{l}\text { Hypothe- } \\
\text { sis } 1 \\
\text { r-selected } \\
\text { types } \\
\text { (Chitty } \\
\text { 1967) } \\
\end{array}$ & $\begin{array}{c}\text { Hypothe- } \\
\text { sis } 2 \\
\alpha \text {-selected } \\
\text { types } \\
\text { (Stenseth } \\
1978 \text { ) }\end{array}$ \\
\hline $\begin{array}{l}\text { Innate capacity for increase } \\
\text { Age at sexual maturity } \\
\text { Ability to winter breed } \\
\text { Juvenile growth rate } \\
\text { Aggression } \\
\text { Dispersal rate } \\
\text { Tolerance to crowding }\end{array}$ & $\begin{array}{l}\text { higher } \\
\text { lower } \\
\text { high } \\
\text { higher } \\
\text { lower } \\
\text { higher } \\
\text { low }\end{array}$ & $\begin{array}{l}\text { lower } \\
\text { higher } \\
\text { low } \\
\text { lower } \\
\text { higher } \\
\text { lower } \\
\text { high }\end{array}$ \\
\hline $\begin{array}{l}\text { Predictions: } \\
\text { (1) Correlation of survival } \\
\text { advantage of large individuals } \\
\text { to population density. } \\
\text { (2) Correlation of survival } \\
\text { advantage of large individuals } \\
\text { to population growth rate. }\end{array}$ & $\begin{array}{l}\text { negative } \\
\text { positive }\end{array}$ & $\begin{array}{l}\text { negative } \\
\text { or } 0\end{array}$ \\
\hline
\end{tabular}

mount this problem by bringing voles (Microtus agrestis) from a declining population into the laboratory. They found that some individuals grew to large size when isolated in the laboratory but other individuals remained as small-size adults. Krebs (1966) confirmed these observations on a declining population of $M$. californicus.

Large size in voles and lemmings may or may not be under genetic control. It is possible that large-size voles are a product of favorable environmental conditions (food, weather) during the phase of increase (Zimmermann 1955). But we will assume in this paper that large size is a heritable trait with sufficient genetic variance that at least some of the cyclic size changes are a product of natural selection. This assumption needs to be tested by estimating the heritability of body size in several species of cyclic voles and lemmings.

If we assume that there is some adaptive value to size in small rodents, we can give a strategic analysis of the Chitty effect. Since large-size voles appear in peak populations, we assume these individuals are at a selective advantage in pre-peak populations, and at a selective disadvantage in declining and low populations. Because of the time lags inherent in rodent biology, the large-size phenotype must be selected for during the phase of increase, and selected against during the decline and low phases.

Selection on large-size voles could operate through birth, death or dispersal rates. In this paper we have been concerned solely with death and dispersal components, since the loss rate we measure in livetrapping studies integrates death and emigration. Large-size voles could have a substantial reproductive advantage for at least 2 reasons. Larger voles may have slightly larger litters (Keller and Krebs 1970, Hasler 1975), but perhaps the most substantial advantage may be in winter breeding. Only large voles are able to breed during the winter (Krebs et al. 1969, Krebs et al. 1976), and individuals that enter a winter in which breeding will occur are at a great advantage if they are large. We have not attempted to analyze reproductive fitness of large and small adults, but we must remember that some of the adaptive advantages of large size may be due to reproduction rather than survival. We can see no simple reproductive disadvantage of large size in voles, and reproductive fitness does not seem to provide any explanation why low populations contain no large animals.

Two completely contrary hypotheses about the biological characteristics of large-size adults can be postulated. One hypothesis suggests that large-size adults may be r-selected genotypes which are at a selective advantage in the increase phase (Chitty 1967). Our interpretation is that these genotypes devote a high proportion of their energy to reproduction by achieving sexual maturity at young ages and breeding during the winter. They produce offspring of high growth rate and high dispersal powers (Myers and Krebs 1971). They are relatively docile, and are not well adapted to life at high population density. The 2 nd hypothesis is very nearly the contrary in identifying large-size adults as $\alpha$-selected genotypes which trigger the decline phase (Stenseth 1978). Under this hypothesis large voles devote more of their energy to spacing behavior and interference competition, and less energy to reproduction. They produce young which mature at older ages and do not breed during the winter. Growth rates of young are lower and relatively few disperse. They are well adapted to life at high densities. Table 5 summarizes these predictions.

The 2 contradictory hypotheses cannot easily be distinguished from data currently available. First, we have no way of distinguishing the large-size genotypes when they are juveniles or in the autumn (Chitty and Chitty 1962). According to the 1st hypothesis, we should observe a predominance of large adults in the increase phase, but we do not because the increase phase occurs rapidly between 1 spring and the next. The large genotypes which produce the increase are visible to us only in the 2nd spring, the spring of the peak yr. Second, we do not know which environmental or social conditions prevent large genotypes from attaining their growth potential. We may observe large animals at the start of the decline (Krebs 1964a) but they disappear in the decline. According to the 2nd hypothesis, declining populations consist predominantly of large genotypes selected for high aggressiveness. However, we never catch large-size adults, either because none survives long enough to attain its full body size, or because behavioral interactions are so severe that growth is restricted. The 1st hypothesis attributes the absence of large animals in declining 
populations to their selective elimination by more aggressive, smaller individuals.

We can use the data discussed in this paper to distinguish these 2 hypotheses. If large phenotypes are an adaptation to crowding, as the 2 nd hypothesis suggests, the correlation between population density and survival differential should be positive (Table 5). Conversely, if large phenotypes are an adaptation to rapid population growth, the correlation between population growth rate and survival differential should be positive.

The data presented in Tables $1-4$ fall into 2 groups. For Microtus californicus and M. ochrogaster the survival advantage of being large is positively related to density and slightly negatively related to population growth. These 2 species fit Hypothesis 2, in which large animals are aggressive, high-density genotypes. For Microtus pennsylvanicus and male M. townsendii, by contrast, the survival advantage of being large is negatively related to density and positively related to population growth rate. These 2 species fit Hypothesis 1, in which large animals are reproductive, low-density genotypes. Our analysis thus suggests that large body size may be used for quite contrary reasons in different species of cyclic voles and lemmings.

The results for Microtus townsendii are noteworthy because it is the only species in which the 2 sexes differ in the adaptive value of large body size. Large female $M$. townsendii are always at a survival disadvantage. We are tempted to suggest that this may be part of the explanation why this species does not show clear population cycles but only annual or irregular fluctuations. Anderson (1975) estimated the heritability of maximum body size in $M$. townsendii as 0 . If this estimate is reliable, the basic assumption of our analysis would be in error and we would have to look elsewhere for an explanation of body-size changes in this species.

One difficulty with this analysis is that it includes only the viability components of fitness and not the reproductive components. The experiment suggested by our analysis is the simple one of raising laboratory colonies from large phenotypes and small phenotypes, and testing for the attributes listed in Table 5. To carry out this experiment, however, wild voles and lemmings must be induced to breed in captivity without strong selection for a "laboratory phenotype."

This analysis rests on the assumption that there are in fact 2 extreme types of individuals in these populations. There may be a continuum of genotypes between the r-type and $\alpha$-type of vole in the real world, but it is crucial that average Darwinian fitness be higher in the 2 extreme forms than in the intermediates. Otherwise some intermediate genotype would come to predominate in the population, and cycles would be lost (Anderson 1975). These assumptions do not state any restrictions on the control of r-type and $\alpha$-type individuals. These could be the developmental products arising from some physiological switch mechanism set by early experiences, or be directly inherited qualities passed from parents to offspring.

Some vole species fluctuate cyclically but do not show the changes in adult size discussed here. Fuller (1977) discussed this problem for Clethrionomys gapperi and concluded that spring growth rate may be a better indicator of changes in the types of individuals than absolute body size. If size is not important in reproduction or in spacing behavior, there would be no need for size to change during a population cycle. Nevertheless the 2 types of individuals described in Table 5 may still exist but be more difficult to identify.

A parallel to the present analysis may be seen in attempts to analyze larger body sizes of mice and voles on islands (Sullivan 1977). Island populations of Peromyscus maniculatus off British Columbia (Redfield 1976) and the Skomer vole (Clethrionomys glareolus) off Britain (Jewell 1966) have adults of larger than average body size. These populations are usually interpreted as illustrations of $\mathrm{K}$-selection, which is nearly the same as Hypothesis 2 in Table 5. Sullivan (1977) suggested that Hypothesis 1 may be a more accurate description of some island populations of Peromyscus maniculatus. A comparison between small- and largesize adults of islands and the mainland, of the type we have done in this paper, might shed more light on these island questions, and indirectly on the Chitty effect in cyclic rodents.

Body wt is a difficult variable to analyze because it is subject to change for many reasons. A more precise analysis needs to be made of viability differentials by the use of body length or skull width measurements (Anderson 1975). These data, in conjunction with a genetic analysis of heritability of body size would take the problem of the Chitty effect another step toward resolution.

\section{ACKNOWLEDGMENTS}

Data analyzed in this paper were collected by 23 different students and technicians over 15 years. We thank these anonymous coauthors, the National Science Foundation of the United States, and the National Research Council of Canada for supporting these researches. We thank Dennis Chitty, Judy Myers, Robert Moss, Adam Watson, and 2 referees for their helpful comments.

\section{Literature Cited}

Anderson, J. L. 1975. Phenotypic correlations among relatives and variability in reproductive performance in populations of the vole Microtus townsendii. Dissertation. University of British Columbia, Vancouver, British Columbia, Canada.

Batzli, G. O., and F. A. Pitelka. 1971. Condition and diet of cycling populations of the California vole Microtus californicus. Journal of Mammalogy 56:888-901.

Bietz, B. F., P. H. Whitney, and P. K. Anderson. 1977. Weight loss of Microtus pennsylvanicus as a result of trap confinement. Canadian Journal of Zoology 55:426-429.

Boonstra, R. 1976. Experimental studies of the population processes in the vole Microtus townsendii. Dissertation. 
University of British Columbia, Vancouver, British Columbia, Canada.

Chitty, D. 1952. Mortality among voles (Microtus agrestis) at Lake Vyrnwy, Montgomeryshire in 1936-9. Philosophical Transactions of the Royal Society of London, England, Series B, 36:505-552.

. 1967. The natural selection of self-regulatory behaviour in animal populations. Proceedings of the Ecological Society of Australia 2:51-78.

Chitty, H., and D. Chitty. 1962. Body weight in relation to population phase in Microtus agrestis. Pages 77-86 in Symposium Theriologicum, Brno, Czechoslovakia.

Fuller, W. A. 1977. Demography of a subarctic population of Clethrionomys gapperi: size and growth. Canadian Journal of Zoology 55:415-425.

Fuller, W. A., A. M. Martell, R. F. C. Smith, and S. W. Speller. 1975. High-arctic lemmings, Dicrostonyx groenlandicus. II. Demography. Canadian Journal of Zoology 53:867-878.

Gaines, M. S., and R. K. Rose. 1976. Population dynamics of Microtus ochrogaster in eastern Kansas. Ecology 57:1145-1161.

Gaines, M. S., R. K. Rose, and L. R. McClenaghan, Jr. 1977. The demography of Synaptomys cooperi populations in eastern Kansas. Canadian Journal of Zoology 55:1584-1594.

Hansson, L. 1969. Spring populations of small mammals in central Swedish Lapland in 1964-68. Oikos 20:431-450.

Hasler, J. F. 1975. A review of reproduction and sexual maturation in the microtine rodents. The Biologist 57: 52-86.

Jewell, P. A. 1966. Breeding season and recruitment in some British mammals confined on small islands. Pages 86-116 in I. W. Rowlands, editor. Comparative Biology of Reproduction in Mammals. Academic Press, London, England.

Kalela, O. 1957. Regulation of reproduction rate in subarctic populations of the vole Clethrionomys rufocanus (Sund.). Annales Academiae Scientiarum Fennicae, Series A, IV. Biologica 34:1-60.

Keller, B. L., and C. J. Krebs. 1970. Microtus population biology. III. Reproductive changes in fluctuating populations of $M$. ochrogaster and $M$. pennsylvanicus in southern Indiana, 1965-1967. Ecological Monographs 40:263294.

Koshkina, T. V., and Yu. S. Korotkov. 1975. Regulative adaptations in populations of the red vole (Clethrionomys rutilus) under optimum conditions of its range. Fauna and Ecology of Rodents 12:5-61. (Translated from Russian by W. A. Fuller, University of Alberta, Edmonton, Alberta, Canada.)
Krebs, C. J. 1964a. The lemming cycle at Baker Lake, Northwest Territories, during 1959-62. Arctic Institute of North America Technical Paper 15, Canada.

1964b. Cyclic variation in skull-body regressions of lemmings. Canadian Journal of Zoology 42:631-643.

1966. Demographic changes in fluctuating populations of Microtus californicus. Ecological Monographs 36:239-273.

- 1971. Genetic and behavioral studies in fluctuating vole populations. Pages 243-256 in P. J. Den Boer and G. R. Gradwell, editors. Dynamics of Populations. Proceedings of the Advanced Study Institute on Dynamics of Numbers in Populations, Oosterbeek, Netherlands.

Krebs, C. J., and J. H. Myers. 1974. Population cycles in small mammals. Advances in Ecological Research 8:267399.

Krebs, C. J., B. L. Keller, and R. H. Tamarin. 1969. Microtus population biology: demographic changes in fluctuating populations of $M$. ochrogaster and $M$. pennsylvanicus in southern Indiana. Ecology 50:587-607.

Krebs, C. J., I. Wingate, J. LeDuc, J. A. Redfield, M. Taitt, and R. Hilborn. 1976. Microtus population biology: dispersal in fluctuating populations of $M$. townsendii. Canadian Journal of Zoology 54:79-95.

LeDuc, J., and C. J. Krebs. 1975. Demographic consequences of artificial selection at the LAP locus in voles (Microtus townsendii). Canadian Journal of Zoology 55:1825-1840.

Myers, J. H., and C. J. Krebs. 1971. Genetic, behavioral, and reproductive attributes of dispersing field voles Microtus pennsylvanicus and Microtus ochrogaster. Ecological Monographs 41:53-78.

Newson, J., and D. Chitty. 1962. Haemoglobin levels, growth and survival in two Microtus populations. Ecology 43:733-738.

Redfield, J. A. 1976. Distribution, abundance, size, and genetic variation of Peromyscus maniculatus on the Gulf Islands of British Columbia. Canadian Journal of Zoology $54: 463-474$.

Stein, G. H. W. 1957. Materialen sur Kenntnis der Feldmaus, Microtus arvalis P. Zeitschrift für Säugetierkunde 22:117-135.

Stenseth, N. C. 1978. Demographic strategies in fluctuating populations of small rodents. Oecologia 33:149-172.

Sullivan, T. P. 1977. Demography and dispersal in island and mainland populations of the deer mouse, Peromyscus maniculatus. Ecology 58:964-978.

Zimmermann, K. 1955. Körpergrösse und Bestandsdichte bei Feldmäusen (Microtus arvalis). Zeitschrift für Säugetierkunde 20:114-118. 